\title{
FISILIBILITY STUDY PENAMBAHAN VILLA PADA PT. BAGUS AGRO PELAGA DI KABUPATEN BADUNG (DENGAN PENDEKATAN ASPEK KEUANGAN DAN PEMASARAN)
}

\author{
Bagus Arya Wijaya ${ }^{1}$ I Komang Sumerta ${ }^{2}$ Luh Putu Virra Indah Perdanawati ${ }^{3}$
}

\begin{tabular}{l}
\hline \multicolumn{1}{c}{ Article history: } \\
\hline \\
Submitted: 29 Desember 2020 \\
Revised: 3 Januari 2021 \\
Accepted: 24 Februari 2021 \\
\\
\hline \\
Keywords: \\
Fisibility Study, \\
NPV, \\
IRR, \\
Satisfaction, \\
Price \\
(maximum be 5 keywords) \\
\\
Kata Kunci: \\
Fisibility Study; \\
NPV; \\
IRR; \\
Kepuasan; \\
Harga; \\
\hline
\end{tabular}

\section{Koresponding:}

Fakultas Ekonomi dan Bisnis Universitas Ngurah Rai, Denpasar, Bali, Indonesia. Email:

komang.sumerta@unr.ac.id

\section{Abstract}

The purpose of this study is to determine whether or not the investment in additional villas by PT. Bagus Agro Pelaga in terms of marketing and financial aspects, with analysis techniques using Market Share, Payback Period, Net Present Value, Profitability Index, Internal Rate of Return, and Average Rate of Return. The pricing strategy used is based on perceived value pricing, namely the price is determined by the buyer's impression (perception) of the product being offered, at a competitive price so that all customers can be served well, with promotional strategies carried out in the form of advertising, personal selling, and the public. relation. The results of the measurement of the financial aspects show that the Payback Period = 5 years; Positive Net Present Value $=R p$. 9,201,370,532, -; Profitability Index $=2.06$; Internal Rate of Return $=26.12 \%$ and Average Rate of Return $=36 \%$. Judging from the various aspects of the feasibility study that was studied, with more depth on the aspects of marketing and finance, it shows positive results. So that the investment plan to add villas to PT. Bagus Agro Pelaga is worth doing.

\begin{tabular}{l} 
Abstrak \\
Tujuan penelitian ini adalah mengetahui layak tidaknya investasi \\
\hline penambahan villa yang dilakukan PT. Bagus Agro Pelaga ditinjau dari \\
aspek pemasaran dan keuangan, dengan teknik analisis menggunakan \\
Market Share, Payback Period, NPV Profitability Index, IRR, dan Average \\
Rate of Return. Strategi penetapan harga yang digunakan adalah \\
berdasarkan perceived value pricing yaitu harga ditentukan oleh kesan \\
pembeli (persepsi) terhadap produk yang ditawarkan, dengan harga yang \\
kompetitif sehingga semua pelanggan dapat terlayani dengan baik, dengan \\
strategi promosi yang dilakukan berupa periklanan (advertising), personal \\
selling, dan public relation. Hasil pengukuran aspek keuangan \\
menunjukkan bahwa Payback Period = 5 tahun; Net Present Value positip \\
$=$ Rp. 9.201.370.532,-; Profitability Index = 2,06; Internal Rate of Return = \\
26,12\% dan Average Rate of Return = 36\%. Ditinjau dari berbagai aspek \\
studi kelayakan yang diteliti, dengan lebih mendalam pada aspek \\
pemasaran dan keuangan menunjukkan hasil yang positip. Sehingga \\
rencana investasi penambahan villa pada PT. Bagus Agro Pelaga layak \\
untuk dilaksanakan.
\end{tabular}

Fakultas Ekonomi dan Bisnis Universitas Ngurah Rai, Denpasar, Bali, Indonesia. ${ }^{2}$

Email: komang.sumerta@unr.ac.id

Fakultas Ekonomi dan Bisnis Universitas Ngurah Rai, Denpasar, Bali, Indonesia. ${ }^{3}$

Email: virra.indah@unr.ac.id 


\section{PENDAHULUAN}

Perkembangan perekonomian Kabupaten Badung sebagai penghasil pendapatan asli daerah (PAD) terbesar di Bali, yang sebagian besar berasal dari sektor pariwisata, juga mengalami ketimpangan di mana Badung Selatan (Nusa Dua, Kuta, dan Jimbaran) memiliki pendapatan yang mendominasi dari perolehan PAD Kabupaten Badung apabila dibandingkan dengan Badung Utara (Petang, Mengwi, dan Abiansemal) (Patera, 2016). Apabila ditinjau dari sumber daya alam, lingkungan dan masyarakatnya Badung Utara mempunyai potensi yang cukup besar dan cukup menjanjikan dalam mendukung peningkatan perekonomian daerah, masyarakat, bangsa dan negara sehingga Pemerintah Daerah Tingkat II Badung menetapkan Badung Utara sebagai kawasan agrowisata agar terjadi kerjasama yang saling menguntungkan antara pertanian dengan pariwisata. Seiring dengan tujuan tersebut maka BTDC (Bali Tourism Development Center) yang memiliki lahan yang cukup luas di daerah Pelaga bekerja sama dengan PT. Puri Bagus Citra Lestari ingin memberikan suatu sumbangan nyata kepada masyarakat Badung Utara melalui pengembangan suatu obyek wisata baru yang terintegrasi antara pertanian dan pariwisata dengan nama Bagus Agro Pelaga, dimana pengelolaan perusahaan diserahkan sepenuhnya kepada PT. Puri Bagus Citra Lestari yang telah berpengalaman dalam bidang pariwisata Obyek wisata ini merupakan mix farming dan sustainable farming yang berupa kombinasi berbagai macam hasil pertanian dan fasilitas penunjang dalam suatu kawasan yang ditata dengan baik sehingga mampu menarik wisatawan untuk melihat dan menghasilkan sayuran, serta buah - buahan yang memiliki nilai tambah (value added) yang bisa memberikan inspirasi kepada petani di sekitarnya untuk mencoba melakukan hal yang serupa. Bila dikaitkan dengan agriculture, sustainable mendikripsikan sistem pertanian adalah "mampu untuk mempertahankan produktivitas dan berguna untuk masyarakat untuk jangka waktu yang lama.

Sampai dengan tahun 2019 kawasan agrowisata Pelaga sudah memiliki 7 (tujuh) unit villa, di mana jumlah ini apabila dikaitkan dengan permintaan pasar menjadi sangat tanggung. Beberapa travel agent yang mengunjungi kawasan Bagus Agro Pelaga menyarankan agar pihak pengelola melakukan penambahan jumlah villa sehingga minimal mencapai jumlah 20 (dua puluh) unit villa sehingga mampu menampung jumlah wisatawan yang dihandle oleh travel agent tersebut. Adanya permintaan jumlah villa disambut positif oleh pihak pengelola Bagus Agro Pelaga karena apabila dikaitkan dengan pengalaman PT. Puri Bagus Citra Lestari dalam mengelola villa maka jumlah ideal adalah 20 (dua puluh) unit ke atas, sehingga villa tersebut nantinya akan mampu menampung kedatangan wisatawan dalam jumlah group. Jumlah 20 (dua puluh) unit villa juga akan memberikan kesempatan pihak Puri Bagus untuk menjadikan villa di kawasan agrowisata Pelaga sebagai suatu bagian paket tour terintegrasi dengan villa yang lain yang akan dijual oleh Puri Bagus sehingga diharapkan akan memiliki bargaining position yang lebih baik dalam pemasaran ke travel agent.

Menurut Yoeti (2000) istilah agrowisata adalah hasil pertanian, peternakan, atau perkebunan sebagai daya tarik bagi wisatawan. Dalam hal ini terdapat interaksi antara wisatawan dengan hasil agro itu sendiri, baik langsung dipetik di tempat tersebut atau hasilnya langsung dinikmati pada saat berkunjung ke lokasi agro. Jadi wisatawan tidak hanya melihat - lihat obyek wisata tetapi juga dapat secara langsung berinteraksi dengan segala sesuatu yang mereka lihat di obyek tersebut. Menurut Husnan dan Suwarsono (1999), maksud dari studi kelayakan usaha/proyek adalah suatu penelitian tentang layak atau tidaknya suatu proyek usaha untuk dilaksanakan dengan berhasil.

Sedangkan menurut Sutojo (2002), hal - hal yang perlu dikaji dalam studi kelayakan proyek meliputi empat aspek utama yaitu : pasar, teknis, manajemen, finansial. Namun demikian pengkajian aspek - aspek dalam studi kelayakan tidak selalu dilakukan secara keseluruhan, tergantung dari jenis

Fisibility Study Penambahan Villa Pada PT.Bagus Agro Pelaga di Kabupaten Badung (Dengan Pendekatan Aspek Keuangan dan Pemasaran) 
proyeknya. Proyek investasi dapat berupa proyek pengembangan dan proyek baru. Proyek pengembangan tidak perlu dilakukan pengkajian semua aspek, sementara itu proyek baru sangat perlu pengkajian seluruh aspek. Adapun aspek - aspek tersebut adalah yang pertama aspek pasar. Secara umum pasar didefinisikan sebagai tempat berlangsungnya pertukaran barang atau jasa antara penjual dan pembeli. Pendapat lain menjelaskan bahwa pasar adalah sekumpulan pembeli aktual dan potensial sebagai produk. Namun Kotler (1997) mendefinisikan pasar sebagai semua pelanggan potensial yang memiliki kebutuhan atau keinginan tertentu yang sama, dan mungkin bersedia serta mampu melaksanakan pertukaran untuk memuaskan kebutuhan dan keinginan itu. Suatu pasar itu timbul karena adanya permintaan dan penawaran akibatnya muncul peluang pasar, pesaing serta pangsa pasar yang harus diraih oleh si penjual atau produsen. Potensi pasar harus dilihat dan dievaluasi sebelum produk itu ada. Potensi pasar akan menentukan posisi ada tidaknya pasar, fungsi produk dibuat, rancangan produk terbaik untuk pasar yang akan dimasuki serta tingkat harga yang ditawarkan.

Sementara itu, Sutojo (2002) menjelaskan bahwa lingkup aspek pasar yang perlu dievaluasi meliputi : a) gambaran dimasa yang akan datang, apakah terdapat cukup permintaan pasar yang dapat menyerap barang atau jasa yang akan dihasilkan. b) gambaran bagaimana suasana persaingan dipasar pada masa yang akan datang c) gambaran tentang prospek perkembangan faktor ekstern perusahaan yang dapat mempengaruhi permintaan produk dan suasana persaingan pasar. Selanjutnya aspek teknis. Aspek teknis merupakan aspek yang berkenaan dengan proses pembangunan proyek secara teknis dan pengoperasiannya setelah proyek tersebut selesai. Berdasarkan analisa ini dapat diketahui rancangan awal penafsiran biaya investasi. Dengan demikian merupakan salah satu proyek yang dapat ditawarkan. Menurut Sutopo (2000), aspek teknis meliputi : a) penentuan kapasitas produksi ekonomis proyek; b) jenis teknologi dan peralatan produksi yang diusulkan untuk dipakai; c) pemilihan lokasi dan letak proyek serta ; d) pengadaan bahan baku, bahan pembantu dan fasilitas pendukung.

Penentuan lokasi proyek penting dilakukan karena terkait erat dengan fasilitas pendukung setelah proyek berjalan. Menurut Husnan \& Suwarsono (1999) ada dua variabel yang diperlukan dalam pemilihan lokasi yaitu variabel primer dan sekunder. Variabel primer antara lain ketersediaan bahan mentah, letak pasar yang dituju, tenaga listrik dan air, tenaga kerja dan fasilitas transportasi. Sedangkan variabel sekunder meliputi hukum dan peraturan nasional maupun daerah mengenai lokasi, iklim dan keadaan tanah, sikap dari masyarakat setempat serta rencana masa depan perusahaan yang terkait dengan perluasan. Ketiga merupakan aspek manajemen. Menurut Sutojo (2002), aspek manajemen mencakup jenis penelitian dan jumlah tenaga kerja yang diperlukan mengelola dan mengoperasikan proyek. Sejalan dengan itu diteliti pula kualifikasi tenaga kerja, sumber pengadaan tenaga kerja dan program pelatihan yang diperlukan.

Proses pengorganisasian menyangkut tiga prosedur yaitu : a) merinci semua pekerjaan yang harus dilakukan untuk mencapai tujuan perusahaan, b) membagi semua beban kerja ke dalam berbagai aktivitas yang secara logis dapat dijalankan oleh seseorang, c) menyusun mekanisme untuk mengkoordinir pekerjaan dari para anggota organsiasi ke dalam satuan yang harmonis dan terpadu. Sementara itu, struktur organisasi menggambarkan lima aspek yaitu : a) pembagian pekerjaan, b) manajer dan bawahan, c) tipe pekerjaan yang dilakukan, d) pengelompokan bagian-bagian pekerjaan dan e) tingkatan manajemen (Husnan \& Suwarsono, 1999).

Keempat merupakan aspek keuangan. Evaluasi aspek keuangan rencana investasi proyek mencakup beberapa hal berikut : a) penyusunan anggaran investasi, yaitu jumlah dana yang dibutuhkan untuk membangun dan mengoperasikan proyek, b) struktur pembiayaan proyek yang akan dibangun, c) perkiraan jumlah standar biaya produksi, d) kemampuan proyek menghasilkan keuntungan, e) analisis Break Even Point (Sutojo, 2002). Selanjutnya masih menurut Sutojo, bahwa

Fisibility Study Penambahan Villa Pada PT.Bagus Agro Pelaga di Kabupaten Badung (Dengan Pendekatan Aspek Keuangan dan Pemasaran) 
jumlah dana yang diperlukan untuk membangun dan mengoperasikan proyek dikelompokkan menjadi dua, yaitu : a) dana yang dibutuhkan untuk membiayai pengadaan barang modal atau modal tetap (fixed investment) dan b) dana yang dibutuhkan untuk membiayai kebutuhaan modal kerja awal neto (net initial working capital). Arus kas akan selalu ada dalam pengembangan Kawasan agrowisata. Penghasilan dan arus kas akan mengarah pada keputusan yang konsisten Günay \& Fatih (2020). Perkiraan arus kas konstruksi yang akurat sangat penting dalam keberhasilan mengelola biaya selama pelaksanaan proyek bangunan (Cheng, et.al., 2020). Manajemen arus kas yang baik akan membantu manajer mengontrol perkiraan biaya, implementasi rencana pengendalian serta mengontrol biaya tambahan, memastikan keberhasilan proyek (Le, et.al., 2020; Cheng, et.al., 2020; Yang \& Kim, 2020).

Menurut Husnan dan Suwarsono (1999), aktiva tetap yang diperlukan untuk investusi bisa diklasifikasikan sebagai berikut : 1) aktiva tetap berwujud seperti tanah dan bangunan, 2) aktiva tetap tidak berwujud seperti biaya-biaya pendahuluan dan biaya sebelum operasi. Untuk menaksir kebutuhan dana aktiva tetap, digunakan informasi tentang kebutuhan fisik dan harga-harga. Lebih lanjut dikatakan bahwa kebutuhan fisik dapat didasarkan atas rancangan garis besar dan spesifikasi yang belum lengkap atau didasarkan atas pengalaman dengan proyek yang sama atau agak berbeda di tempat lain. Sementara itu, harga didasarkan atas harga yang masih berlaku, harga di waktu lalu maupun perkiraan harga. Selanjutnya pemilihan sumber dana pada dasarnya bertujuan untuk memilih sumber dana yang pada akhirnya bisa memberikan kombinasi dengan biaya yang terendah, dan tidak menimbulkan kesulitan likuiditas bagi proyek atau perusahaan yang mensponsori proyek tersebut. Sumber-sumber dana dapat diperoleh dari ; a) modal sendiri, b) saham biaya atau saham preferen, c) obligasi, d) kredit bank e) leasing dan $f$ ) project finance. Masih menurut Husnan \& Suwarsono (1994), komponen aliran kas dikelompokkan menjadi tiga bagian yaitu : a) aliran kas permulaan, yaitu aliran kas yang berhubungan dengan pengeluaran investasi b) aliran kas operasional, yaitu kas yang diperoleh berdasarkan laba setelah pajak ditambah penyusutan dan waktunya ditentukan berdasarkan umur ekonomis proyek dan c) aliran kas terminal, umumnya terdiri dari aliran kas nilai sisa investasi tersebut dan pengembalian modal kerja. Menurut Sutojo (2002), evaluasi profitabilitas proyek dapat dilakukan dengan mempergunakan dua macam metode, yaitu metode konvensional dan metode discounted cash flow. Dalam metode konvensional dipergunakan dua macam tolok ukur profitabilitas, yaitu ; a) Payback Period dan b) Average Rate of Return, sedangkan dalam metode discounted cash flow dipergunakan tiga macam tolok ukur profitabilitas, yaitu ; a) Net Present Value, b) Internal Rate of Return dan c)Profitability Index.

\section{METODE PENELITIAN}

Lokasi penelitian ini bertempat di PT. Bagus Agro Pelaga dan PT. Puri Bagus Citra Lestari yang berkantor pusat di Bagus Discovery Building, Jalan I Gusti Ngurah Rai no. 300 B, Tuban, Kuta, Badung, Bali. Adapun waktu penelitian dimulai pada bulan Oktober 2006 sampai dengan bulan Oktober 2007. Sumber data dalam penelitian ini ditentukan berdasarkan jumlah kedatangan wisatawan ke Kabupaten Badung sebagai populasi dengan wisatawan yang mengunjungi obyek wisata alam di Kabupaten Badung sebagai sampel, dikarenakan konsep investasi yang akan dikembangkan merupakan kombinasi antara wisata dengan alam yang diperoleh dari buku tahunan Dinas Pariwisata Kabupaten Badung. Penelitian ini menggunakan metode analisis deskriptif dengan pendekatan kuantitatif dan kualitatif untuk memecahkan masalah dengan variable - variabel yang akan diteliti. Adapun rumus yang digunakan adalah:

Fisibility Study Penambahan Villa Pada PT.Bagus Agro Pelaga di Kabupaten Badung (Dengan Pendekatan Aspek Keuangan dan Pemasaran) 


$$
\mathrm{ROR}=\frac{\mathrm{W} \times \mathrm{L}}{\mathrm{Ks} \times \mathrm{Df} \times 365}
$$

Keterangan:

$\mathrm{ROR}=$ room occupancy rate (tingkat hunian kamar)

$\mathrm{W}=$ proyeksi wisatawan pada villa yang dikelola PT. Puri Bagus Citra Lestari (orang)

$\mathrm{L} \quad=\quad$ lama tinggal (hari)

Ks $=$ jumlah kamar tersedia (kamar)

Df $=$ faktor pengganda (orang/kamar)

Perhitungan laba rugi digunakan untuk mengukur arus dari pendapatan dan beban selama suatu selang waktu tertentu. Persamaan perhitungan laba rugi dasar adalah:

Pendapatan - Beban $=$ Laba

Perhitungan Pay Back Period seperti berikut ini :

Pay Back Period $=($ investasi awal / penerimaan periodik $) \times 100 \%$

Metode Net Present Value. Metode ini adalah menghitung selisih antara nilai sekarang investasi dengan nilai sekarang penerimaan - penerimaan kas bersih di masa yang akan datana (Husnan \& Suwarsono, 1994). Formula yang dipergunakan untuk menghitung Net Present Value berdasarkan Gray et. al. (1991) seperti berikut ini :

$$
\mathrm{NPV} \underset{\mathrm{t}=0}{=\sum^{\mathrm{n}}} \frac{\mathrm{B}_{\mathrm{t}}-\mathrm{C}_{\mathrm{t}}}{(1+i)^{\mathrm{t}}}
$$

Keterangan :

$\mathrm{Bt}=$ keuntungan pada tahun $\mathrm{t}$

$\mathrm{Ct} \quad=$ biaya pada tahun $\mathrm{t}$

$\mathrm{i} \quad=$ tingkat bunga pada periode $\mathrm{t}$

$\mathrm{t} \quad=$ periode investasi $(\mathrm{t}=0,1,2, \ldots, \mathrm{n})$

Formulasi untuk menghitung IRR menurut Kadariah (1994 : 54) seperti di bawah ini :

$$
\mathrm{IRR}=i_{1}+\left(\mathrm{NPV}_{1} \frac{i_{2}-i_{1}}{\mathrm{NPV}_{1}-\mathrm{NPV}_{2}}\right)
$$

Keterangan :

IRR = Internal Rate of Return

i1 = Tingkat bunga ke-1

i2 = Tingkat bunga ke-2

NPV1 = NPV ke-1

NPV2 $=$ NPV ke-2

Fisibility Study Penambahan Villa Pada PT.Bagus Agro Pelaga di Kabupaten Badung (Dengan Pendekatan Aspek Keuangan dan Pemasaran) 
Analisis Sensitifitas dilakukan untuk mengkaji pengaruh perubahan unsur - unsur dalam aspek finansial terhadap keputusan yang dipilih, misalnya perubahan $10 \%$ terhadap biaya operasional dan tingkat hunian. Pada analisis sensitifitas ini dilakukan perhitungan pada peningkatan biaya operasional dan penurunan tingkat hunian kamar, dengan asumsi perubahan lain tidak terjadi.

\section{HASIL DAN PEMBAHASAN}

Terjadi penurunan kunjungan wisatawan dari tahun 2016 hingga 2019. Hal ini mengindikasikan minat wisatawan dalam berkunjung ke Kabupaten Badung cenderung berkurang. Walaupun terjadi pengurangan yang cukup signifikan akan tetapi tidak mengurangi citra Badung sebagai salah satu tujuan wisata. Market share yang dapat dijadikan pedoman dalam analisa invetasi penambahan villa pada PT. Bagus Agro Pelaga sebesar 28\% dari total kunjungan wisatawan ke Kabupaten Badung.

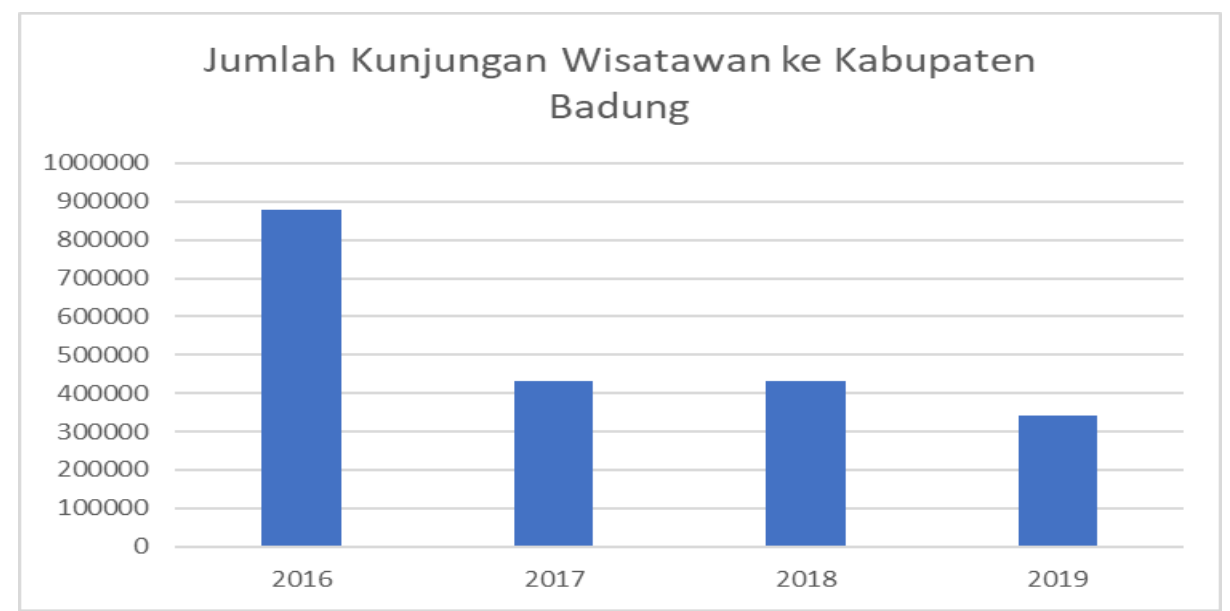

Gambar 1. Jumlah kunjungan wisatawan ke Kabupaten Badung Sumber: Badung dalam angka, 2020

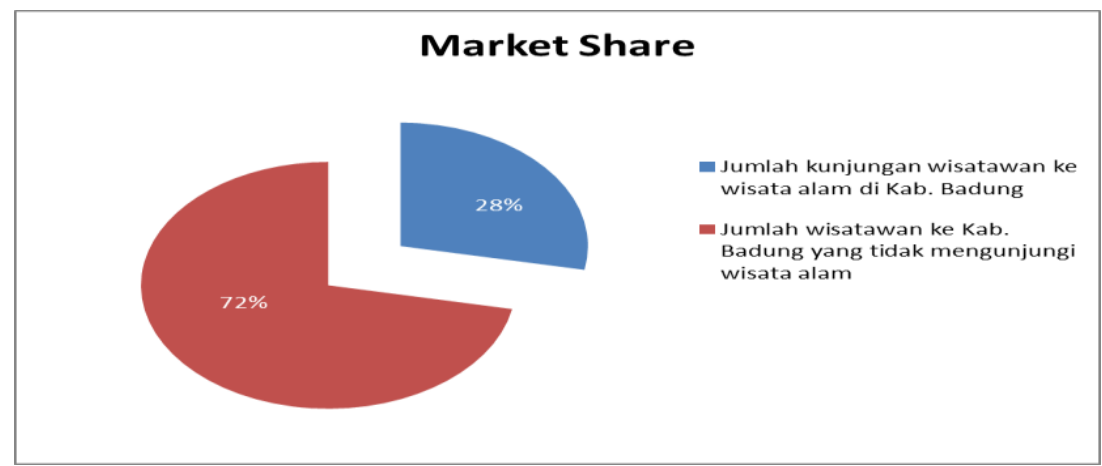

Gambar 2. Market Share Kunjungan Wisatawan ke Kabupaten Badung Sumber: Data diolah, 2020

Fisibility Study Penambahan Villa Pada PT.Bagus Agro Pelaga di Kabupaten Badung (Dengan Pendekatan Aspek Keuangan dan Pemasaran) 
Tabel 1

Nilai Investasi Penambahan Villa pada PT. Bagus Agro Pelaga

\begin{tabular}{|c|c|c|c|}
\hline \multicolumn{4}{|c|}{ COST \& MEANS OF FINANCING } \\
\hline DESCRIPTION & TO BE FINANCE & TOTAL & $\%$ \\
\hline \multicolumn{4}{|l|}{ I. FIXED INVESTMENT. } \\
\hline Land & - & - & $0,00 \%$ \\
\hline Building \& civil work & $6.400 .000 .000,00$ & $6.400 .000 .000,00$ & $76,92 \%$ \\
\hline Fixture Furniture \& Equiptment & $1.920 .000 .000,00$ & $1.920 .000 .000,00$ & $23,08 \%$ \\
\hline SUB TOTAL & $8.320 .000 .000,00$ & $8.320 .000 .000,00$ & $96,07 \%$ \\
\hline \multicolumn{4}{|l|}{ II. DEFERRED CHARGES } \\
\hline Architec / drowing Fee & $83.200 .000,00$ & $83.200 .000,00$ & $31,25 \%$ \\
\hline Notarial Fee \& Permits & $83.200 .000,00$ & $83.200 .000,00$ & $31,25 \%$ \\
\hline Grand Opening Expenses & $41.600 .000,00$ & $41.600 .000,00$ & $15,63 \%$ \\
\hline Supervision Fee & $16.640 .000,00$ & $16.640 .000,00$ & $6,25 \%$ \\
\hline Others & $41.600 .000,00$ & $41.600 .000,00$ & $15,63 \%$ \\
\hline SUB TOTAL & $266.240 .000,00$ & $266.240 .000,00$ & $3,07 \%$ \\
\hline III.WORKING CAPITAL & $73.848 .825,32$ & $73.848 .825,32$ & $0,85 \%$ \\
\hline GRAND TOTAL & $8.660 .088 .825,32$ & $8.660 .088 .825,32$ & $100,00 \%$ \\
\hline \multicolumn{4}{|l|}{ MEANS OF FINANCING } \\
\hline$B T D C$ & 4.416.645.300,91 & 4.416.645.300,91 & $51,00 \%$ \\
\hline PURI BAGUS & $4.243 .443 .524,41$ & $4.243 .443 .524,41$ & $49,00 \%$ \\
\hline GRAND TOTAL & $8.660 .088 .825,32$ & $8.660 .088 .825,32$ & $100,00 \%$ \\
\hline
\end{tabular}

Sumber: PT. Bagus Agro Pelaga, 2020

Tabel 2

Hasil Perhitungan Nilai Investasi Penambahan Villa pada PT. Bagus Agro Pelaga

\begin{tabular}{cc}
\hline Keterangan & Nilai \\
\hline Payback Period & 5 tahun 3 bulan \\
Net Present Value & Rp 775.009 .176 \\
Profitability Index & 1,089 \\
Internal Rate of Return & $21,41 \%$ \\
Average Rate of Return & $24,01 \%$ \\
\hline
\end{tabular}

Sumber: Hasil Perhitungan, 2020

Berdasarkan hasil pengujian data, maka diperoleh hasil perhitungan nilai investasi yang ditunjukkan pada Tabel 2 di atas. Pada kajian aspek pasar atau pemasaran, market demand analysis dalam melakukan studi kelayakan investasi ini, selain memerlukan data intern dari perusahaan PT. Bagus Agro Pelaga, juga diperlukan data pembanding dari perusahaan lain yang memiliki usaha sejenis. Karena di daerah Pelaga (Badung Utara) tidak terdapat usaha sejenis, maka dipilihlah Villa

Fisibility Study Penambahan Villa Pada PT.Bagus Agro Pelaga di Kabupaten Badung (Dengan Pendekatan Aspek Keuangan dan Pemasaran) 
Puri Bagus Lovina dan Villa Puri Bagus Candidasa yang merupakan satu grup usaha dari PT. Puri Bagus Citra Lestari sebagai perusahaan pembanding, selain karena perusahaan ini memiliki pangsa pasar wisatawan yang memiliki karakteristik yang sama dengan rencana pasar villa yang akan dikembangkan, juga karena letak usahanya berada di Propinsi Bali. Alasan lainnya adalah kedua villa tersebut, saat ini menguasai pangsa pasar di kabupatennya masing - masing.

Berdasarkan data jumlah kunjungan wisatawan mancanegara ke Kabupaten Badung tidak mencerminkan secara spesifik bahwa trend kunjungan wisatawan mancanegara adalah negatif. Hal ini terindikasi dari data tahun 2017 dengan jumlah wisatawan mancanegara yang berkunjungan sebesar 5.697.739 orang, pada tahun 2018 sebesar 6.070.473, dan pada tahun 2019 sebesar 6.275.210 orang (Bali dalam angka, 2020), hal ini menunjukkan bahwa potensi wisatawan mancanegara sangat besar dan cukup menjanjikan walaupun rentan digoyang oleh berbagai isu seperti di bidang keamanan dan kesehatan. Jumlah kunjungan wisatawan mancanegara ini dapat dijadikan acuan dalam mengembangkan peluang usaha baru seperti penambahan villa dengan target market adalah wisatawan mancanegara di Kabupaten Badung.

Ditinjau dari jumlah kedatangan wisatawan yang menunjungi wisata alam di Kabupaten Badung dari tahun 2016 - 2019, terdapat kondisi pada obyek wisata yang dikelola dengan manajemen yang baik seperti Uluwatu dan Taman Ayun, memiliki jumlah permintaan pasar yang cenderung meningkat dan cukup besar apabila dibandingkan dengan obyek wisata dengan pengelolaan manajemen yang kurang baik. Hal ini belum lagi ditunjang oleh kelengkapan sarana pendukung obyek wisata seperti villa yang menyatu dengan obyek wisata tersebut.

Secara kuantitatif data jumlah permintaan pasar akan villa di Kabupaten Badung, dengan menggunakan rata-rata tingkat kunjungan wisatawan ke obyek wisata alam di Kabupaten. Dari hasil perhitungan diperoleh bahwa peramalan pertumbuhan kunjungan wisatawan ke obyek wisata alam adalah 95,87 \% dari tahun sebelumnya dengan hasil kajian tersebut setiap tahunnya memiliki standar deviasi dari estimasi peramalan pasar tersebut sebesar $4,13 \%$.

Berdasarkan pengamatan peneliti, persaingan antar villa di Bali dalam memperebutkan peluang bisnis penyewaan villa sangatlah ketat. Pangsa pasar penyewaan villa di Bali sebagian besar dikuasai oleh keberadaan villa-villa berbintang di kawasan Badung Selatan seperti Nusa Dua, Kuta dan Jimbaran. Sedangkan di Kawasan Badung Utara sendiri, pangsa pasarnya masih terbuka lebar karena belum ada pesaing yang mendirikan villa untuk tujuan komersial di daerah tersebut. Peluang pasar yang cukup potensial bagi bisnis villa PT. Bagus Agro Pelaga yang dapat dilihat dari jumlah wisatawan yang didatangkan oleh beberapa travel agent rekanan PT. Puri Bagus Citra Lestari yang menyatakan komitmennya untuk menggunakan villa di Bagus Agro Pelaga. Dimana apabila peluang ini dapat dikelola dengan baik disertai dengan penerapan pelayanan yang terbaik kepada setiap wisatawan yang berkinjung ke villa PT. Bagus Agro Pelaga maka akan dapat memberikan profit/laba yang cukup menguntungkan bagi perusahaan.

Pada tahap marketing strategy, penelitian ini mempertimbangkan penggunaan metode marketing mix atau bauran pemasaran sebagai strategi pemasarannya. Marketing mix adalah kelompok variabel-variabel yang dapat dikendalikan oleh pihak manajemen PT. Bagus Agro Pelaga dengan mengetahui reaksi dari pengguna atau penyewa villa. Variabel-variabel ini terdiri dari product, price, place dan promotion. Produk yang ditawarkan PT. Bagus Agro Pelaga adalah berupa layanan jasa penyewaan villa untuk memenuhi kebutuhan wisatawan akan tempat beristirahat yang menyatu dengan agrobisnis dengan udara yang masih segar serta lokasi yang mudah dijangkau.

Harga ditetapkan oleh pihak manajemen berdasarkan tujuan perusahaan yang berorientasi pada pangsa pasar mancanegara dan domestik. Dengan menetapkan harga yang cukup kompetitif,

Fisibility Study Penambahan Villa Pada PT.Bagus Agro Pelaga di Kabupaten Badung (Dengan Pendekatan Aspek Keuangan dan Pemasaran) 
diharapkan akan dapat meningkatkan minat wisatawan untuk menyewa villa di Pelaga. Hal ini tentu saja dengan mempertimbangkan kemampuan daya beli wisatawan, kondisi internal perusahaan serta penentuan posisi perusahaan. Salah satu strategi yang baik dalam meningkatkan penjualan perusahan adalah dengan menetapkan harga sewa villa yang relatif fleksibel dengan memberikan contract rate yang kompetitif kepada agen perjalanan di dalam dan luar negeri, memberikan harga khusus untuk pangsa pasar perusahaan - perusahaan, harga spesial pada hari - hari tertentu, dan diskon khusus bagi pelanggan yang datang langsung ke villa PT. Bagus Agro Pelaga serta memberikan penghargaan penghargaan khusus bagi pelanggan yang sudah beberapa kali menginap di villa PT. Bagus Agro Pelaga. Market share atau pangsa pasar rata-rata adalah 28,08 \% masih memberikan peluang dan harapan PT Bagus Agro Pelaga dalam memperoleh keuntungan.

Rencana manajemen PT. Bagus Agro Pelaga melakukan penambahan jumlah villa sejumlah 16 unit juga berpengaruh kepada penambahan jumlah manajemen dan staf yang akan bekerja di Bagus Agro. Saat ini jumlah manajemen dan staf yang bekerja pada PT. Bagus Agro Pelaga berjumlah 18 (delapanbelas) orang, dengan adanya penambahan jumlah villa maka jumlah yang akan ditambah sebanyak 4 (empat) orang, sehingga total manajemen dan staf yang bekerja menjadi 22 (duapuluh dua) orang. Manajemen dan staf tersebut terdiri dari 1 orang general manajer, 2 orang manajer, 2 orang supervisor, dan 14 orang staf pelaksana di lapangan. General manajer dan manajer akan ditunjuk langsung oleh pemilik PT. Bagus Agro Pelaga melalui proses seleksi berdasarkan pengalaman dalam mengelola usaha di bidang pariwisata. Selanjutnya pemilihan staf yang lain akan dilakukan oleh general manajer dan manajer dengan bekerja sama dengan pihak ketiga yaitu STP (Sekolah Tinggi Pariwisata), Universitas Udayana dan BLKP (Balai Latihan Kerja dan Profesional). Adanya kerjasama dengan pihak ketiga diharapkan agar tenaga yang diperoleh adalah tenaga siap pakai dan memiliki keahlian di bidangnya sehingga pengelolaan villa dapat memberikan servis yang terbaik kepada setiap pengunjung yang mengunjungi Bagus Agro Pelaga. Dengan servis yang memuaskan diharapkan kepuasan pelanggan akan tercapai sehingga memberikan stimulus pertumbuhan permintaan yang meningkat, yang secara tidak langsung dapat memberikan peningkatan penyewaan villa dan laba perusahaan.

Terdapat penambahan villa PT. Bagus Agro Pelaga di Daerah Pelaga, Badung Utara akan memberikan manfaat sosial ekonomi bagi pemilik perusahaan, karyawan, masyarakat sekitar maupun pemerintah. Manfaat bagi pemilik perusahaan adalah tambahan pendapatan dan profit dari operasional villa dari tambahan 16 unit villa sehingga pendapatan akan meningkat. Bagi karyawan adalah semakin meningkat dan bervariasinya jenjang karir mereka di perusahaan sehingga akan memacu motivasi kerja karena berkembangnya perusahaan akan dapat meningkatkan kesejahteraan karyawan menjadi lebih baik lagi. Bagi masyarakat sekitar akan berdampak pada semakin terbukanya kesempatan kerja dan berusaha di villa Bagus Agro Pelaga. Bagi pemerintah adalah meningkatnya pendapatan pajak hotel dan restoran serta pajak atas badan usaha yang diperoleh dari pendapatan operasional PT. Bagus Agro Pelaga.

Proyeksi aliran kas operasional disusun dengan melihat data arus kas masuk dan arus kas keluar. Arus kas bersih operasional selama 20 tahun, didapat dengan memasukkan probabilitas kondisi pesimis, moderat dan optimis. Rekapitulasi hasil perhitungannya menunjukkan bahwa seluruh proceed dimana keuntungan neto sesudah pajak plus depresiasi ditambah biaya bunga dikali (1 - Tax) menunjukkan peningkatan yang cukup berarti. 
Tabel 3

Proyeksi Laba Rugi PT. Bagus Agro Pelaga Tahun 2006 - 2025

\begin{tabular}{cccrr}
\hline Tahun & Moderat & $\begin{array}{c}\text { EAT } \\
\text { Optimis }\end{array}$ & Pesimis & $\begin{array}{c}\text { Total EAT yg } \\
\text { diharapkan }\end{array}$ \\
\hline 2006 & 131.878 .120 & 156.107 .796 & 180.337 .471 & 160.953 .731 \\
2007 & 348.250 .152 & 378.492 .807 & 408.735 .462 & 384.541 .338 \\
2008 & 516.061 .908 & 550.879 .774 & 585.697 .639 & 557.843 .347 \\
2009 & 734.758 .245 & 775.295 .474 & 815.832 .704 & 783.402 .920 \\
2010 & 906.067 .291 & 952.039 .129 & 998.010 .967 & 961.233 .496 \\
2011 & 1.101 .132 .515 & 1.150 .739 .050 & 1.200 .345 .585 & 1.160 .660 .357 \\
2012 & 1.301 .518 .190 & 1.355 .631 .128 & 1.409 .744 .067 & 1.366 .453 .716 \\
2013 & 1.577 .523 .509 & 1.637 .886 .264 & 1.698 .249 .019 & 1.649 .958 .815 \\
2014 & 1.736 .442 .426 & 1.800 .961 .611 & 1.865 .480 .797 & 1.813 .865 .449 \\
2015 & 1.896 .011 .815 & 1.963 .139 .668 & 2.030 .267 .522 & 1.976 .565 .239 \\
2016 & 2.065 .482 .624 & 2.135 .219 .145 & 2.204 .955 .665 & 2.149 .166 .449 \\
2017 & 2.245 .844 .994 & 2.318 .190 .182 & 2.390 .535 .370 & 2.332 .659 .220 \\
2018 & 2.383 .099 .261 & 2.458 .053 .117 & 2.533 .006 .973 & 2.473 .043 .888 \\
2019 & 2.588 .621 .137 & 2.666 .183 .661 & 2.743 .746 .184 & 2.681 .696 .165 \\
2020 & 2.808 .639 .681 & 2.888 .810 .872 & 2.968 .982 .063 & 2.904 .845 .110 \\
2021 & 3.044 .604 .559 & 3.127 .384 .418 & 3.210 .164 .277 & 3.143 .940 .390 \\
2022 & 3.237 .512 .705 & 3.322 .901 .231 & 3.408 .289 .758 & 3.339 .978 .936 \\
2023 & 3.510 .313 .616 & 3.598 .310 .810 & 3.686 .308 .004 & 3.615 .910 .249 \\
2024 & 3.804 .339 .099 & 3.894 .944 .961 & 3.985 .550 .823 & 3.913 .066 .133 \\
2025 & 4.121 .711 .611 & 4.214 .926 .140 & 4.308 .140 .670 & 4.233 .569 .046 \\
\hline
\end{tabular}

Sumber: Data diolah, 2020

Cost of Capital dengan struktur pendanaan investasi sebesar $100 \%$ dari dana masing masing pemegang saham dengan komposisi PT. BTDC sebesar 51\% dan PT. Puri Bagus Citra Lestari (PBCL) sebesar 49\% dengan tingkat suku bunga yang disyaratkan oleh masing - masing pemegang saham senilai $20 \%$ sehingga discount rate yang digunakan dari proyek ini sebesar $20 \%$ yang diperoleh dari biaya modal rata-rata tertimbang dengan konsep WACC. Pada analisis Payback Period hasil perhitungan waktu yang diperlukan untuk mengembalikan jumlah dana investasi villa, adalah sebagai berikut:

Perhitungan jangka waktu pengembalian modal dalam investasi villa, adalah:

$$
-\frac{510.768 .364}{2.214 .453 .716} x 12 \text { bulan } \quad=3 \text { bulan. }
$$

Metode NPV ini digunakan untuk mencari selisih antara nilai saat ini (nilai pada saat proyek selesai dibangun) seluruh net cash flow tahunan yang akan diterima investor selama umur ekonomis proyek villa dan nilai (anggaran) investasi proyek. Dengan proceeds investasi ini tidak sama besarnya dari tahun ke tahun, maka perhitungan NPV-nya menjadi: 
Tabel 4

Perhitungan NPV Atas Dasar Discount Rate $20 \%$

\begin{tabular}{cccr}
\hline $\begin{array}{c}\text { Tahun } \\
\text { Ke- }\end{array}$ & $\begin{array}{c}\text { Kas Masuk } \\
\text { ( Proceeds ) }\end{array}$ & DF (20 \% ) & Present Value \\
\hline 1 & 1.014 .201 .731 & 0,8333 & 845.134 .302 \\
2 & 1.237 .789 .338 & 0,6944 & 859.520 .916 \\
3 & 1.411 .091 .347 & 0,5787 & 816.598 .562 \\
4 & 1.636 .650 .920 & 0,4823 & 789.356 .739 \\
5 & 1.862 .481 .496 & 0,4019 & 748.531 .313 \\
6 & 2.008 .660 .357 & 0,3349 & 672.700 .353 \\
7 & 2.214 .453 .716 & 0,2791 & 618.054 .032 \\
8 & 2.497 .958 .815 & 0,2326 & 581.025 .220 \\
9 & 2.714 .665 .449 & 0,1938 & 526.102 .164 \\
10 & 2.877 .365 .239 & 0,1615 & 464.694 .486 \\
11 & 3.049 .966 .449 & 0,1346 & 410.525 .484 \\
12 & 3.233 .459 .220 & 0,1122 & 362.794 .124 \\
13 & 3.431 .923 .888 & 0,0935 & 320.884 .884 \\
14 & 3.640 .576 .165 & 0,0779 & 283.600 .883 \\
15 & 3.863 .725 .110 & 0,0649 & 250.755 .760 \\
16 & 4.102 .820 .390 & 0,0541 & 221.962 .583 \\
17 & 4.362 .746 .936 & 0,0451 & 196.759 .887 \\
18 & 4.638 .678 .249 & 0,0376 & 174.414 .302 \\
19 & 4.935 .834 .133 & 0,0313 & 154.491 .608 \\
20 & 5.256 .337 .046 & 0,0261 & 137.190 .397 \\
\hline & & PV Kas Operasional “Proceeds" & 9.435 .098 .001 \\
\cline { 4 - 4 } & & PV Total Investasi “Outlays” & 8.660 .088 .825 \\
\cline { 4 - 4 } & & & $\mathbf{7 7 5 . 0 0 9 . 1 7 6}$ \\
\hline
\end{tabular}

Sumber: Data diolah (2020)

Metode Analisis Profitability Index (PI) digunakan untuk mengukur profitabilitas rencana investasi proyek dengan jalan membandingkan jumlah seluruh PV net cash flows dan salvage value dengan nilai investasi proyek investasi villa, sehingga didapatkan:

$$
P I=\frac{P V \cdot \text { Proceeds }}{\text { PV.Outlays }}=\frac{R p \cdot 9 \cdot 435 \cdot 098.001}{R p \cdot 8 \cdot 660.088 .825}
$$

$$
=1,089 \text {. }
$$

Usulan investasi memiliki nilai PI lebih besar daripada 1, maka usul investasi dapat diterima. Metode Analisis Internal Rate of Return (IRR) digunakan untuk menghitung tingkat bunga yang menyamakan nilai sekarang investasi villa dengan nilai sekarang penerimaan-penerimaan kas bersih di masa-masa mendatang. Adapun perhitungannya sebagai berikut :

$$
\mathrm{r}=\mathrm{P} 1-\mathrm{C} 1 \frac{P_{2}-P_{1}}{C_{2}-C_{1}}
$$

Keterangan :
$\mathrm{r}=\quad$ IRR yang dicari
$\mathrm{P} 1=$ Tingkat bunga ke-1
$\mathrm{C} 1=\mathrm{NPV}$ ke- 1
$\mathrm{P} 2=$ Tingkat bunga ke-2
$\mathrm{C} 2=\mathrm{NPV}$ ke-2

Fisibility Study Penambahan Villa Pada PT.Bagus Agro Pelaga di Kabupaten Badung (Dengan Pendekatan Aspek Keuangan dan Pemasaran) 
Proyek investasi villa memberikan tingkat IRR diatas $20 \%$ sehingga proyek tersebut dinilai menguntungkan. Metode Analisis Average Rate of Return (ARR) mengukur profitabilitas proyek investasi villa dengan cara membagi jumlah rata-rata keuntungan yang diperoleh selama umur ekonomis proyek dengan jumlah rata-rata investasi dana kemudian dikalikan seratus persen. Sesuai hasil perhitungan pada lampiran 9, diperoleh nilai ARR sebesar 24,01\% lebih besar dibandingkan patokan ARR yang ditentukan oleh investor sebesar $20 \%$. Maka ditinjau dari segi profitabilitas, proyek investasi villa dikatakan layak untuk dilaksanakan.

Analisis Sensitivitas bertujuan untuk mencari variabel yang paling sensitive diantara variabel perubahan pendapatan sewa villa dan variabel biaya operasional terhadap penilaian kelayakan investasi dalam rencana pengembangan usaha jasa penyewaan villa PT. Bagus Agro Pelaga, maka perlu dilakukan perhitungan analisis sensitivitas. Analisis ini erat kaitannya dengan perhitungan operational cash flow PT. Bagus Agro Pelaga selama 20 tahun kedepan. Dengan penetapan kondisi dalam 3 (tiga) kategori, yaitu pesimis, moderat, dan optimis dengan probabilitas masing-masing sebesar $0,20,0,40$ dan 0,40 sesuai hasil perhitungan standar deviasi $(\sigma)=4,13 \%$. Penilaian analisis sensitivitas secara kuantitatif dilakukan dengan mengkondisikan pendapatan rata-rata villa sebesar 75 $\%$ dan $125 \%$ dari pendapatan rata-rata villa yang diestimasikan dari perhitungan sebelumnya. Kemudian kedua variabel tersebut dibandingkan untuk menghasilkan variabel mana yang paling besar perubahannya terhadap penilaian investasi.

\section{SIMPULAN DAN SARAN}

Dari aspek pasar atau pemasaran, penambahan villa di PT Bagus Agro Pelaga, Kecamatan Petang, Badung Utara sangatlah potensial untuk memberikan sinergy bagi PT. Puri Bagus Citra Lestari (PBCL) dalam membuat paket menginap yang bisa ditawarkan kepada travel agent karena karakteristik travel agent yang selama ini telah bekerjasama dengan PT. PBCL biasanya memerlukan villa minimum 7 (tujuh) villa dalam setiap kali pemesanan. Sehingga penambahan villa sejumlah 16 (enambelas) villa di Bagus Agro Pelaga memberikan posisi tawar yang lebih menguntungkan bagi PT. PBCL dihadapan travel agent yang memerlukan paket menginap yang bervariasi dengan jumlah villa yang memadai. Sedangkan bagi PT. BTDC, penambahan villa di PT. Bagus Agro Pelaga akan memberikan tambahan pendapatan baik dari nilai sewa lahan maupun pembagian keuntungan. Di lihat dari segi permintaan pasar, terdapat potensi pangsa pasar penyewaan villa yang positif dalam meningkatkan keuntungan perusahaan. Pada aspek teknik, ketersediaan berbagai fasilitas pendukung di sekitar PT. Bagus Agro Pelaga ditambah dengan selesainya jembatan Tukad Bangkung memberikan nilai tambah bagi perusahaan sehingga lebih memudahkan akses suplai peralatan dan perlengkapan yang diperlukan perusahaan selama proses pembangunan villa dan operasional pengirirman berbagai keperluan operasional perusahaan. Pada aspek manajemen. Dengan team manajemen yang telah berpengalaman serta kolaborasi dengan manajemen PT. Puri Bagus Citra Lestari, akan dapat mempercepat kinerja PT. Bagus Agro Pelaga dalam mencapai tujuannya.

Pada aspek sosial ekonomi. Investasi proyek penambahan villa PT. Bagus Agro PElaga akan memberikan dampak positif baik bagi pemilik perusahaan, karyawan, masyarakat sekitar maupun pemerintah. Pada aspek keuangan dapat disimpulkan yakni Payback Period investasi villa selama 5 tahun 3 bulan, dikatakan menguntungkan karena payback periodnya lebih pendek daripada yang disyaratkan oleh pemilik modal yaitu 8 tahun. NPV positif dan lebih besar daripada nol sebesar Rp. 775.009.176,- menunjukkan bahwa investasi penambahan villa tersebut akan dapat meningkatkan

Fisibility Study Penambahan Villa Pada PT.Bagus Agro Pelaga di Kabupaten Badung (Dengan Pendekatan Aspek Keuangan dan Pemasaran) 
keuntungan pemilik modal. PI sebesar 1,089 lebih besar daripada 1, menunjukkan bahwa usulan investasi villa tersebut dapat diterima. IRR sebesar $21,41 \%$ lebih besar daripada biaya modal yang dipandang layak oleh pemilik modal sebesar $20 \%$. Hal ini menunjukkan bahwa rencana investasi tersebut dinilai menguntungkan.

ARR sebesar 24,01\% lebih besar daripada patokan ARR yang ditentukan investor sebesar $20 \%$ sehingga dari segi profitabilitas, proyek investasi tersebut layak untuk dilaksanakan. Hasil analisis sensitivitas, menunjukkan bahwa variabel pendapatan sewa gedung merupakan variabel yang sangat peka terhadap keberhasilan rencana investasi penambahan villa pada PT. Bagus Agro Pelaga.

Ditinjau dari berbagai aspek studi kelayakan yang diteliti, rencana investasi penambahan villa tersebut sangat layak untuk dilanjutkan PT. Bagus Agro Pelaga. Saran yang dapat diberikan adalah perlunya mengkombinasikan antara agro dengan villa sehingga akan memberikan alternatif baru bagi paket wisata yang ditawarkan kepada travel agent baik yang merupakan rekanan maupun travel agent yang lain. Karena kombinasi yang tepat akan menjadi suatu terobosan baru dalam pemasaran produk pariwisata Bali serta menjadi bukti nyata kalau pariwisata bukan merupakan ancaman bagi pertanian.

\section{REFERENSI}

Aryadnyana. K. (2003). Studi Kelayakan Pembangunan Villa The Saren di Seminyak - Kuta ( Tesis ). Denpasar : Universitas Udayana.

Brigham, E.F. \& Houston, J.F. (2001). Manajemen Keuangan. Edisi Kedelapan. Jakarta : Erlangga

Cheng, C. A., Li, S., \& Zhang, E. X. (2020). Operating cash flow opacity and stock price crash risk. Journal of Accounting and Public Policy, 39(3), 106-717.

Cheng, M. Y., Cao, M. T., \& Herianto, J. G. (2020). Symbiotic organisms search-optimized deep learning technique for mapping construction cash flow considering complexity of project. Chaos, Solitons \& Fractals, 138, 109-869.

Fabozzi, F.J. (2000). Manajemen Investasi. Edisi Pertama. Jakarta: Salemba Empat.

Fauzi, A., Arifin, J. dan Fakhrudin, M. (2001). Aplikasi Excel dalam Finansial Terapan. Jakarta : PT. Elex Media Komputindo.

Fitzgerald, E.V.K. (1978). Public Sector Investment Planning for Developing Country. 1sted. The MacMillan India Press Ltd., Madras.

Gitman, L.J. (2000). Principles of Managerial Finance. 9th ed. Addison Wesley, Reading Massachusetts.

Günay, F., \& Fatih, E. C. E. R. (2020). Cash flow based financial performance of Borsa İstanbul tourism companies by Entropy-MAIRCA integrated model. Journal of multidisciplinary academic tourism, 5(1), 29-37.

Haming, M., dan Basalamah, S. (2003). Studi Kelayakan Investasi : Proyek dan Bisnis. Jakarta : Penerbit PPM.

Horne, J.C. van. (1981). Financial Management and Policy. 5th ed. Prentice-Hall of India. New Delhi.

Husnan, S. dan Pudjiastuti, E. (2002). Dasar - Dasar Manajemen Keuangan. Edisi Ketiga. Yogyakarta: UPP AMP YKPN.

Husnan, S. dan Suwarsono. (1999). Studi Kelayakan Proyek. Edisi Ketiga. Yogyakarta: UPP AMP YKPN.

Le, T., Vu, T., \& Nguyen, V. (2020). Identifying factors influencing on the cash flow of construction companies: Evidence from Vietnam stock exchange. Management Science Letters, 10(1), 255264.

Patera, I M. (2016). Pariwisata dan Kemiskinan di Kabupaten Badung, Bali. Disertasi. Program Studi Pariwisata Program Pasca sarjana, Universitas Udayana.

Purba, J. (2002). Studi Kelayakan Pembangunan Apartemen Hotel di Patra Jasa Bali Resort ( Tesis ). Denpasar : Universitas Udayana.

Fisibility Study Penambahan Villa Pada PT.Bagus Agro Pelaga di Kabupaten Badung (Dengan Pendekatan

Aspek Keuangan dan Pemasaran)

Bagus Arya Wijaya, I Komang Sumerta dan Putu Virra Indah Perdanawati 
Riyanto, B. (1997). Dasar-Dasar Pembelanjaan Perusahaan. Edisi Keempat. Yogyakarta . BPFE.

Sharpe, W.F., Alexander, G.J. dan Bailey, J.V. (1997). Investasi. Edisi Indonesia. Pearson Education Asia Pte. Ltd. dan PT. Prenhallindo.

Sutojo, S. 2002. Studi Kelayakan Proyek : Konsep, Teknik dan Kasus. Edisi Baru. Jakarta : PT. Damar Mulia Pustaka.

Yang, D., \& Kim, H. (2020). Managerial overconfidence and manipulation of operating cash flow: Evidence from Korea. Finance Research Letters, 32(1), 101-343.

Yoeti, O., A. 2000, Ekowisata : Pariwisata Berwawasan Lingkungan Hidup, Jakarta: PT. Pertja 